\title{
Separation of ibuprofen drugs enantiomers by using chiral carbon nanotube with molecular dynamics simulation
}

\author{
Melahatsadat Rasoolidanesh ${ }^{1}$, Masoud Darvish Ganji $^{2}$ \\ ${ }^{1}$ Department of Nanochemistry, Faculty of Pharmaceutical Chemistry, Tehran Medical Sciences, Islamic Azad \\ University, Tehran, Iran \\ ${ }^{2}$ Department of Chemistry, Qaemshahr Branch, Islamic Azad University, Qaemshahr, Iran
}

\begin{abstract}
Background: The separation of drug enantiomers in the pharmaceutical industry is of great importance since most organic compounds are chiral. The main purpose of this study was to calculate the binding energy of ibuprofen isomers interacting with the CNT, according to various adsorption configurations. Moreover, we have evaluated the performance of (16.4) chiral carbon nanotube for separation of ibuprofen enantiomers. Also, the interaction between R- and S-isomers of ibuprofen with the outer surface and internal sidewall of chiral CNT was investigated.

Materials and methods: The performance of (16.4) carbon nanotube has been evaluated for separation of ibuprofen enantiomers using molecular dynamics simulation. Quantum computations were also utilized, optimizing the molecular structure of the drug and the amount of charge of each atom in the ibuprofen enantiomers.

Results: The energy difference between the left and right-handed enantiomers inside the (16.4) carbon nanotube was equal to $0.5 \mathrm{eV}(11.5 \mathrm{kcal} / \mathrm{mol})$, while the adsorbed enantiomers on the outer surface of nanotube did not differ in energy.

Conclusion: The results of this study showed that there was a sufficient difference between the adsorption energy of the enantiomers adsorbed inside the (16.4) chiral carbon nanotube; therefore we can anticipate this nanotube will work effectively in the process of separating drug enantiomers.
\end{abstract}

Keywords: Ibuprofen, Carbon nanotube, Chirality, Enantioseparation, Molecular dynamics simulation.

Cited as: Rasoolidanesh M, Darvish Ganji M. Separation of ibuprofen drugs enantiomers by using chiral carbon nanotube with molecular dynamics simulation. Medical Science Journal of Islamic Azad University, Tehran Medical Branch 2020; $30(3)$ : $227-236$.

Correspondence to: Masoud Darvish Ganji

Tel: +989125833192

E-mail: Ganji_md@yahoo.com

ORCID ID: 0000-0001-8003-9682

Received: 13 Apr 2019; Accepted: 2 Jul 2019 
مجله علوم يزشكى دانشگاه آزاد اسلامى

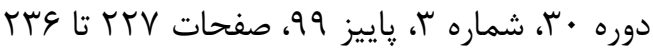

Original

Article

\section{جداسازى انانتيومرهاى داروى ايبويروفن توسط نانو لوله كربنى كايرال با استفاده از شبيه سازى ديناميك مولكولى}

ملاحت سادات رسولى دانش' ، مسعود درويش گنجىى

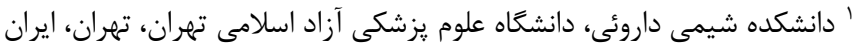

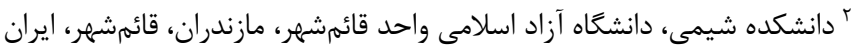

جكيده

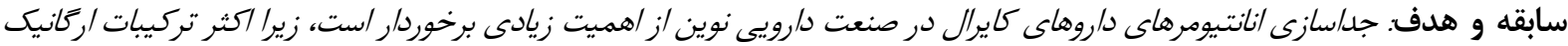

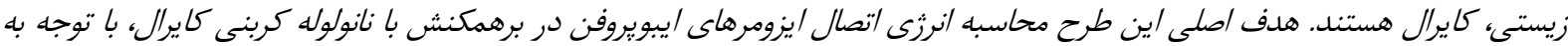

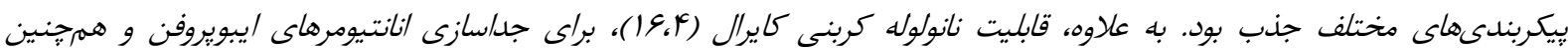

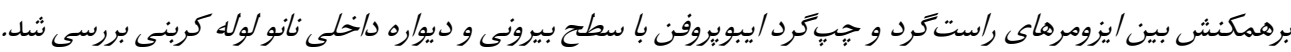

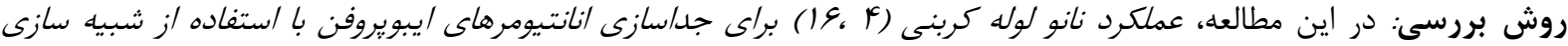

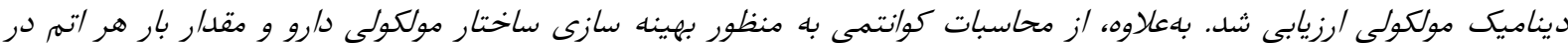

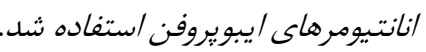

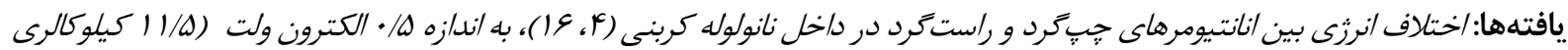
بر مول) بود، در حالى كه /ين انانتيومرهاى جذب شده بر روى نانولوله داراى اختاف انرزى نبون انبود.

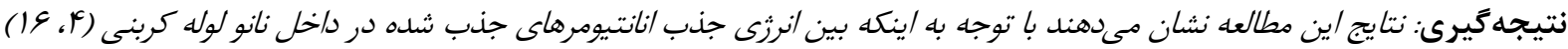

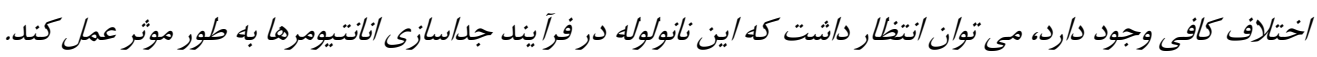

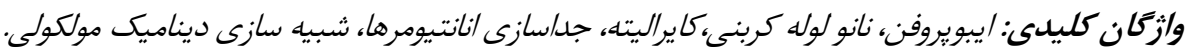

متفاوتى دارند. بيشتر واكنشهاى زيست شـيميايى كـه در بـدن مقدمه

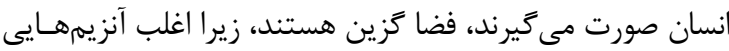
كه در بدن وجود دارند، فعال نورى هستند و به طور متفاوتى بـا

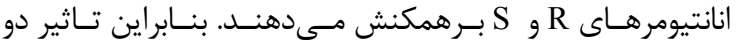
انانتيومر R و S، بر بدن متمايز است. تقريبـا نيمسى از داروهــا بــه صورت مخلوط راسميك ((مخلـوط مسـاوى از هـر دو انـانتيومر عرضـه مسى ( (S g R)

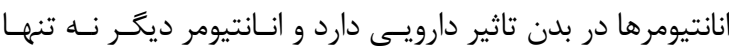

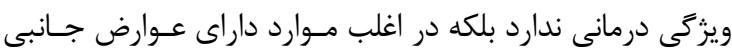

است و حتى در بعضى موارد، اثرات سمى دارد ( ( أ، ).

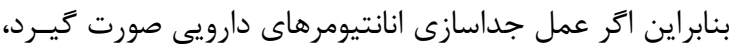

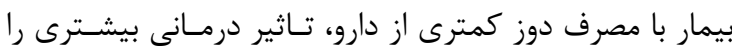

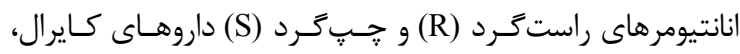

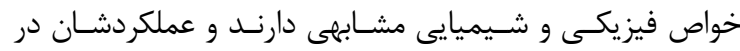

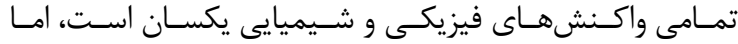

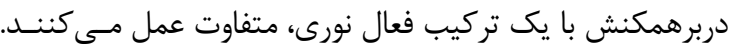

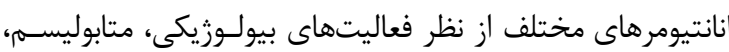
خواص فارماكوديناميكى و فارماكوكينتيكى قابليـتهــاى بسـيـيار

آدرس نويسنده مسئول: قائم شهر ، دانشكده شيمى ، دانشكاه آزاد اسلامى واحسـ قـائم شهـر ، مازنسـران،

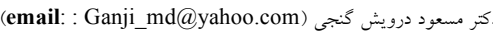
ORCID ID: 0000-0001-8003-9682 تاريخ دريافت مقاله:

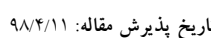


ايبويروفن، يك مسكن قوى است و خواص دارويى مهمى مانند

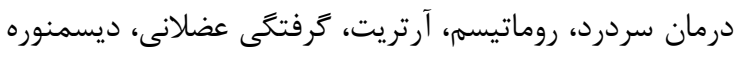

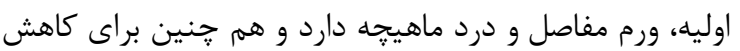
تب ، تسكين درد خفيف و متوسط ناشسى از سـرماخوردكى يـا

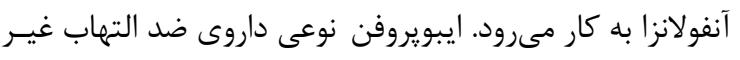

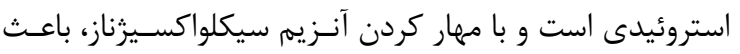

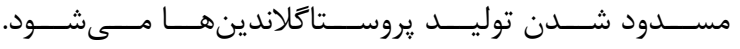

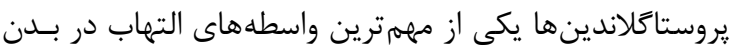

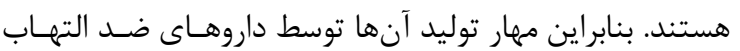

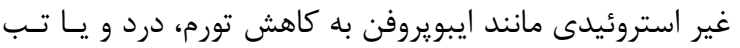

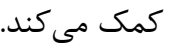
اين مولكول داراى دوانانتيومر مختلف است:

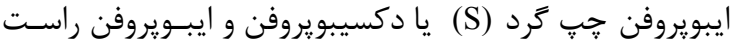

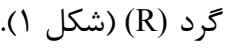

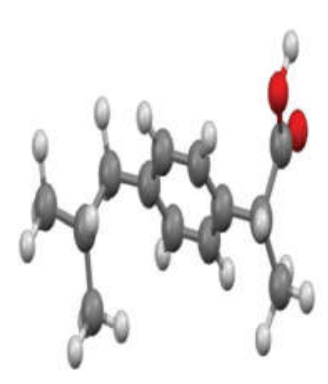

(a)

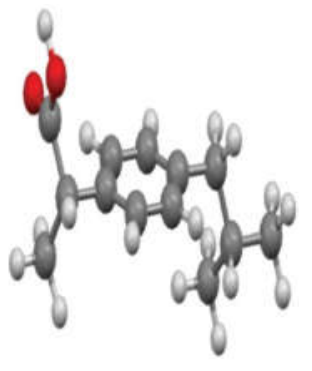

(b)
شكل ا. نمايش انانتيومرهاى ايبويروفن (آ) ايبـويروفن (R) و (ب)

ايبويروفن (S).

ايبويروفن به عنوان يك تركيب راسميك عرضه مسىشـود، امـا

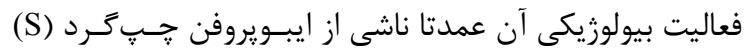

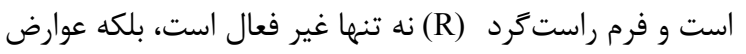

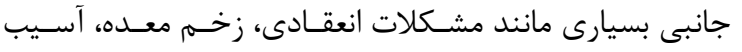

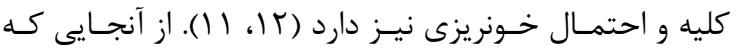

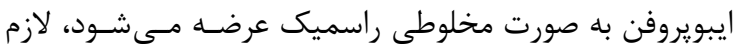

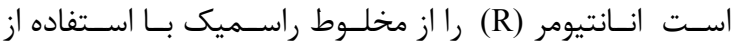

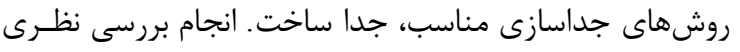

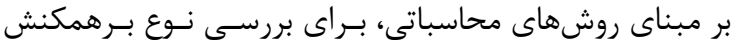

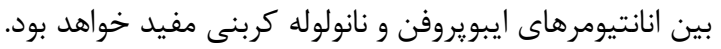

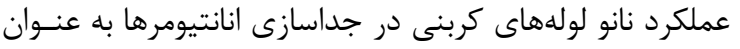

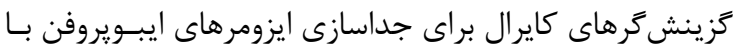

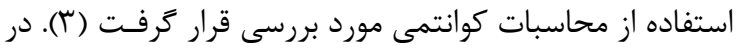

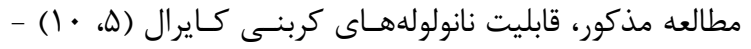
نقص دار و بـدون نقـص - در جــا سـازى ايزومرهـاى كـايرال
احساس مى كند و از طرفى تحت تاثير عوارض جـانبى مربـوط

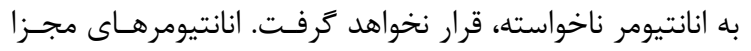

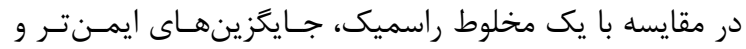

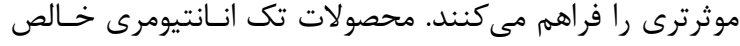

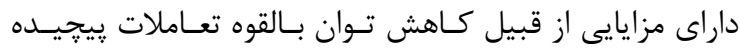

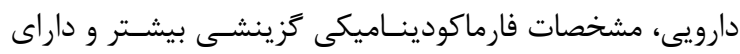

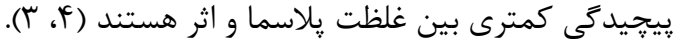

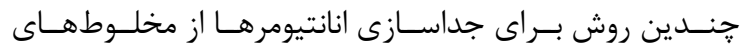
راسميك در داروهاى كايرال استفاده مسىشـود (فرآينـد هـاى

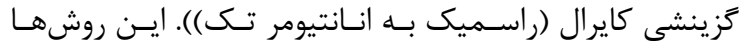

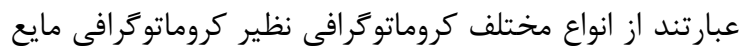

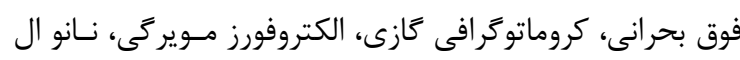

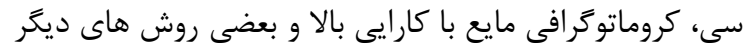

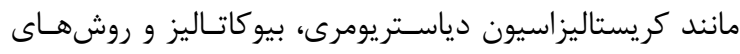

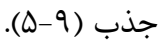

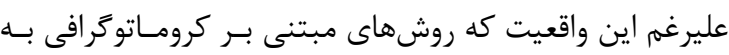

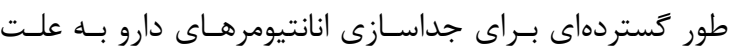

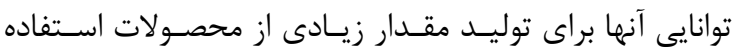

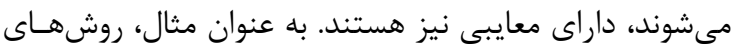

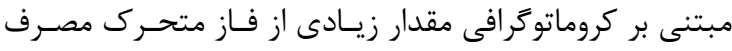

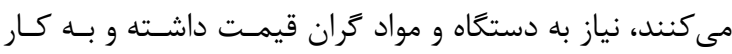

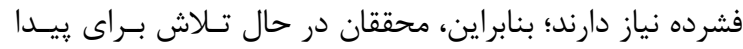

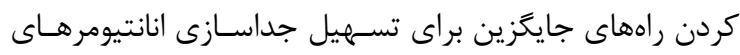
دارويى هستند.

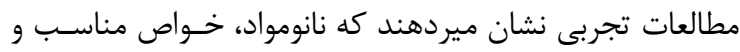

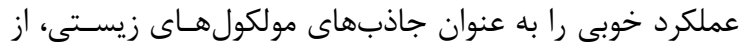

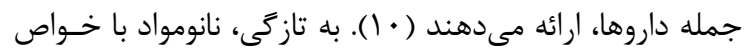
شيميايى، فيزيكى، مكانيكى و حرارتى خاص مانند نانولولههاى

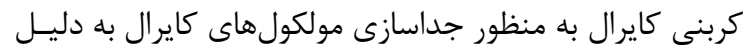

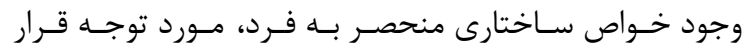

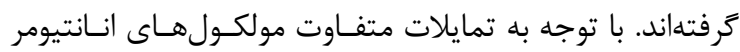

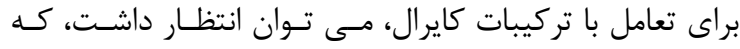

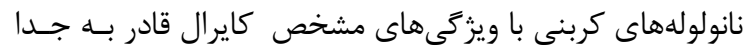
كردن دو انانتيومر باشند. براى اين منظور، توانايىهاى نانولولههاى كربنسى كـايرال را در

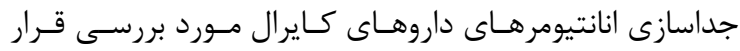

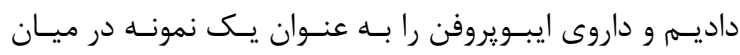
مولكولهاى كايرال در نظر كرفتيه. ايبويروفن تركيـب كـايرال

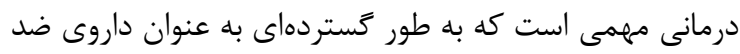

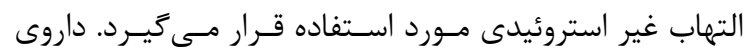


كريسـتالهـ (General Utility Lattice Program :GULP) انجام شد.

اين برنامه بهينه سازى هندسى و شبيه سـازىهـاى ديناميـك مولكولى مربوط به مولكولها ، خوشهها، سيستمهاى دو بعـدى و سه بعدى را به وسيله طيف گستردهاى از مدلهاى يتانسـيل

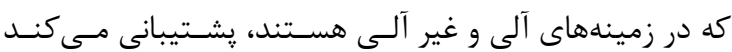
(1 (I). مدلهاى يتانسيل شامل مدل يوسته، اتم هاى جاسـازى

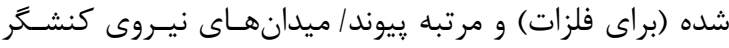

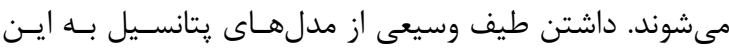
معنى است كه مى توان ساختارهاى متنوعى مانند زئوليتهـا و غشاهاى فلزى را بر روى بسترهاى نيمه هادى طراحى كرد. در اين طرح از ميدان نيروى كنشخر Reactive Force :ReaxFF)

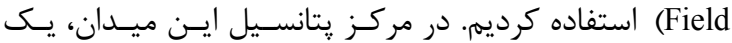
رابطه مرتبه يِيوند/مرتبه انرزى وجود دارد. مرتبههـاى ييونــ از فاصله بين اتمى به دست آمدهاند و در هر تكــرار امكـان تغييـر اتصال وجود دارد. ايسن مرتبـههـاى قييونـــ در تمـامى جمـلات

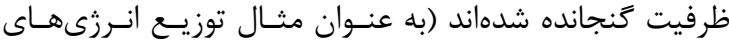

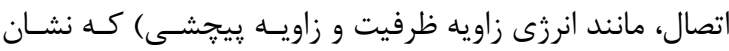
مى دهد مرتبه انرزى به مرتبه ييوند، وابسته است.

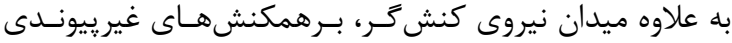

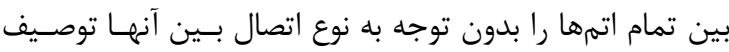

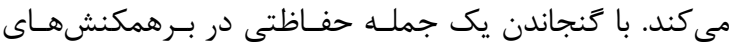
واندروالسى و كولومبى، برهمكنشهاى غير ييوندى كوتـاه بـرد

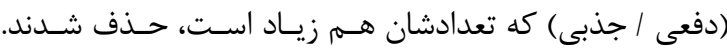
ميدان نيروى كنش گر با هدف ارائه يك يتانسيل قابـل انتقـال مى تواند براى طيف گستردهاى از محيطهـاى شـيميايى مـورد استفاده قرار زيرد. براى اطمينـان از قابليـت انتقـال آن، دسـتورالعمل كلـى زيــر بذيرفته شده است: • عدم وجود انفصال در انرزى يا نيرو ، حتى در هنگام وقوع واكنشها

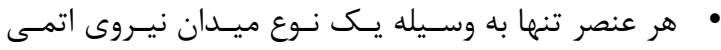
توصيف مىشود. • ميدانهاى نيروى كنشخر اكسيثن در اكسيدهاى فلـزى و در مولكولهاى آلى، توسط مولفـههـاى يكسـانى توصـيف

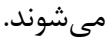

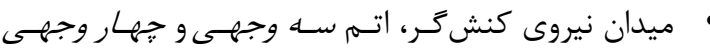
جداكانه براى كربن ندارد؛ اين روش هيبريداسيون اتسمهــا را به وسيله محيط شيميايى اطرافشان تعيين مي كند.

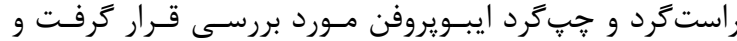
برهمكنش بين دو انانتيومر ايبويروفن و سطح بيرونى و ديـواره

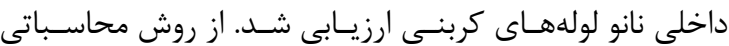
نظريه تابعى جگالى (DFT) با اصلاح نيروهاى يراكندگى بـراى سيستمهاى مورد مطالعه استفاده شد. نتايج اين مطالعه نشـان

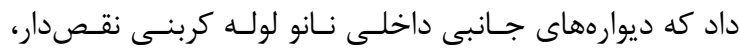

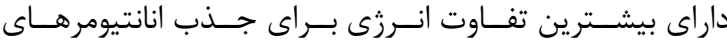
ايبويروفن هستند. بين جفت انانتيومرهاى در نظر گرفته شـده

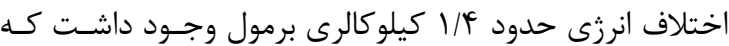
نشان مىدهد كه اين نانولولهها در فرآيند جداسازى انانتيومرها موثر عمل مى كنند. در اين مطالعه، سيستمهاى مورد نظــر بــهـ

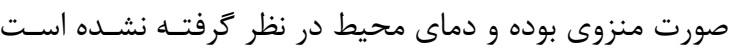
(Y). همجنين قطر نانولوله به اندازه كافى بزرگ نبود تا دارو به راحتى بتواند در حالتهاى مختلف استقرار يابد كه اين موضوع

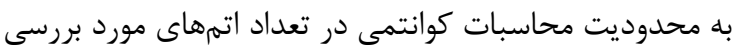
مربوط مى شود. به علاوه، با انجام فرايند بجينه سازى بـا روش كوانتمى، به سختى مىتوان به كمينه سطح انرزى سامانههـاى مولكولى دست يافت و نيازمند اجراى شـبيه سـازى ديناميـك بـ بــ مولكولى است. در اين طرح، به منظور بررسى امكان اسـتفاده از نانولولـهـــاى

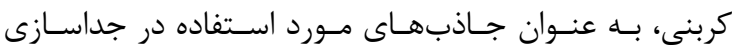

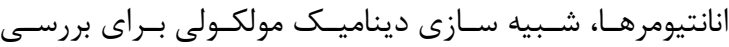
برهمكنش بين ايزومرهاى ايبويروفن و سطح بيرونى و داخلى

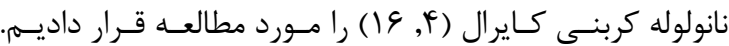
شبيه سازى در شرايط محيطى (دما و حلال) انجـام مسى شــود.

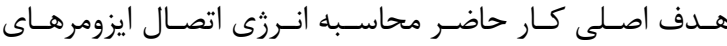

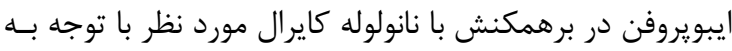
ييكربندىهاى مختلف جذب، بود. اطلاعات دقيـقتـر در مــورد روشهاى محاسـباتى و همجنــين نتـايج بـه دسـت آمـده، در بخشهاى بعدى به طور كامل بيان شده است.

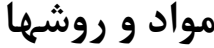

در ايسن مطالعـه، عملكــرد نـانو لولـه كربنــى (4 ، ع|) بـراى

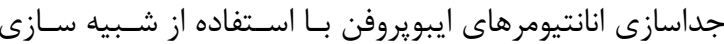
ديناميك مولكولى، مورد ارزيابى قرار گرفت. بــه عـلاوه، شـبيه

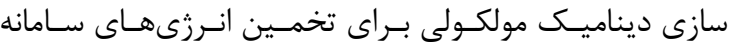
انانتيومر-نانولوله كربنى مورد استفاده قرار گرفت. شبيه سـازى

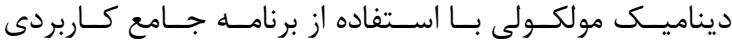




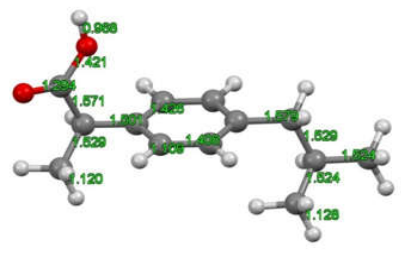

(ب)

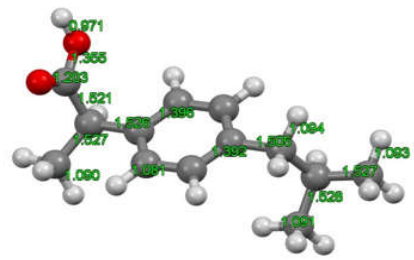

(I)

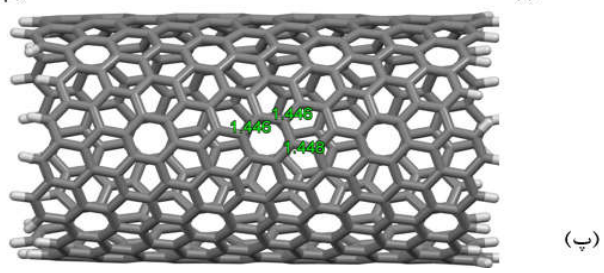

شكل ז. ساختار مولكولى بهينه شده (آ) ايبويروفن راست كرد با استفاده از روش مكانيك كوانتمى DFT ، (ب) ايبويروفن راست كرد با

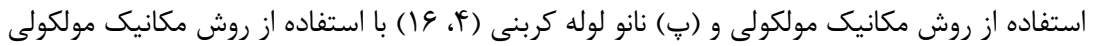

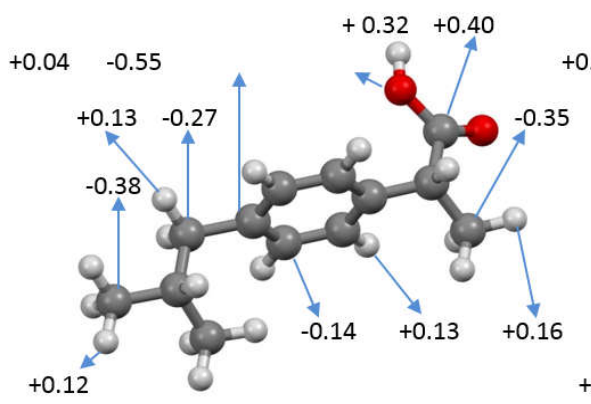

(ب)

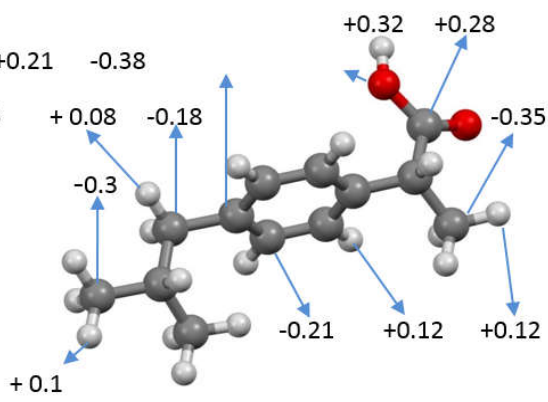

(I)

شكل r. آناليز بار مولكول ايبويروفن راست كرد به روش (آ) مكانيك كوانتمى و (ب) كلاسيكى (ب)

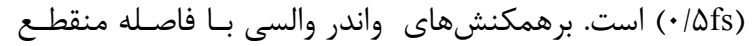

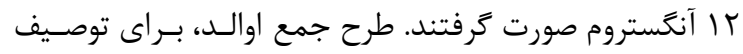

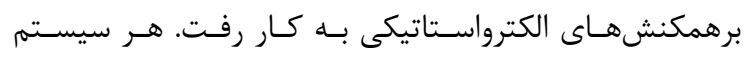

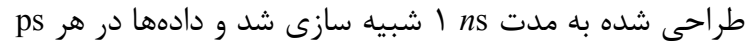

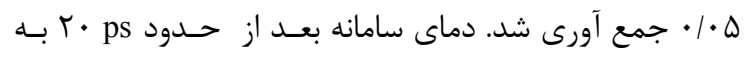
تعادل رسيد.

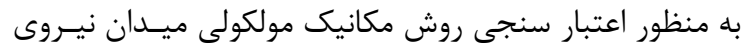

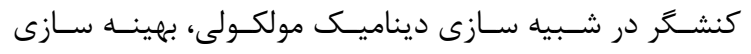

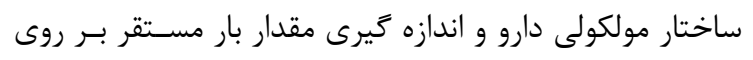

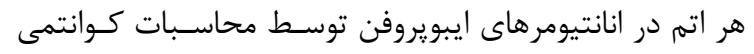

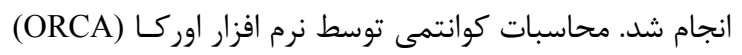

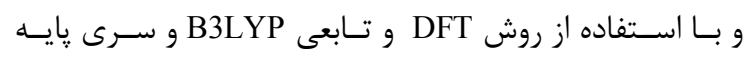

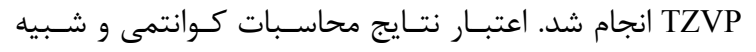

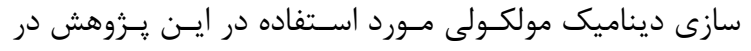
كارهاى يزوهشى ديكر نشان داده شده است (1) (19 1).

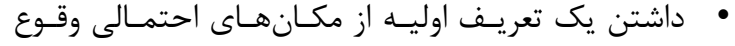

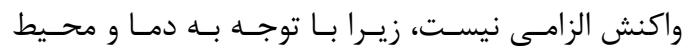

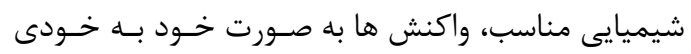
اتفاق مىافتند (4) (1).

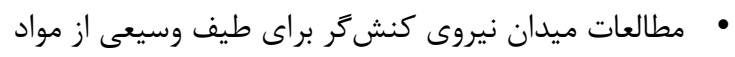

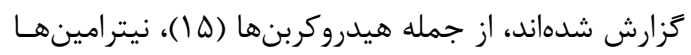

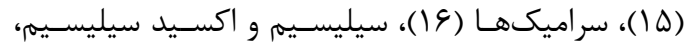

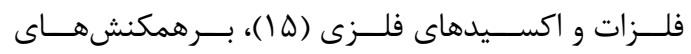

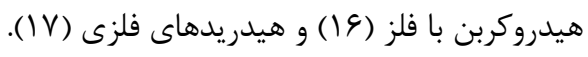

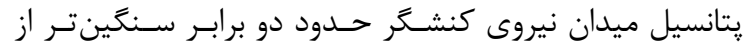

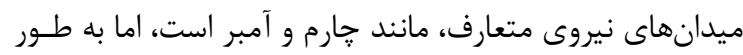

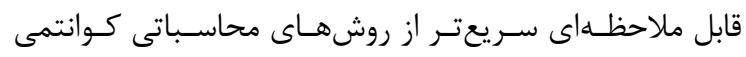
آغازين (ab initio) است.

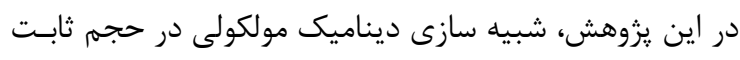

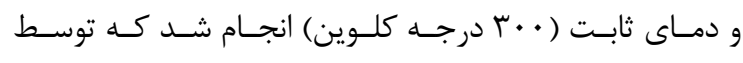

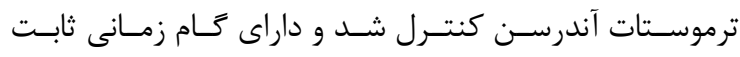


نتايج انرزى كل سيستم نسـبت بــهـ زمـان شـبيه سـازى بـراى

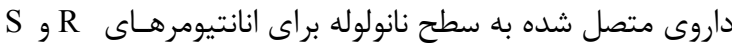
در نمودار r نمايش داده شده است. منحنى نهاى به دائ دست آمده

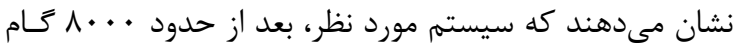

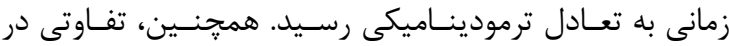
مقادير انرزى كل سيستم بـراى انانتيومرهـاى R و S مشـاهدي

نشد.

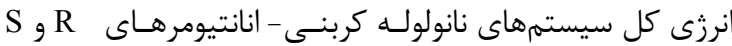
در حـدود ( ولت بر بر آورد شد.

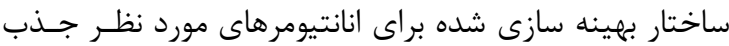
شده بر روى نانولوله در شكل ه نشان داده شده است. با توجـهـ

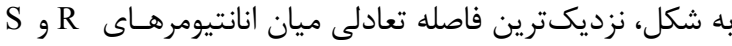

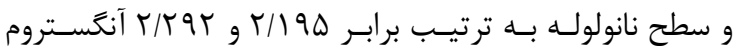
است. همجنين فاصله حلقههاى آروماتيك در دارو و نانولوله به به

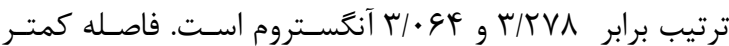

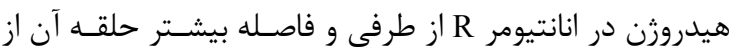

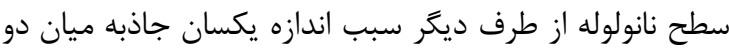
انانتيومر شده و در نتيجه انرزى كل دو سيستم با يكديخر برابر آنا داديه

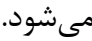
برهمكنش داروى كيسوله شده داخل نانولوله نشان مى دهد كه

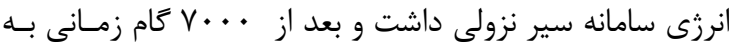

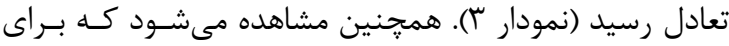

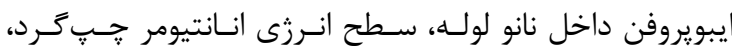

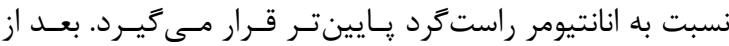

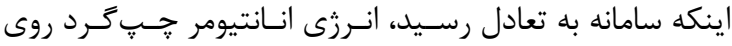

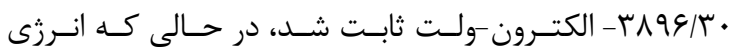

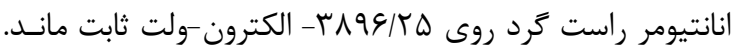

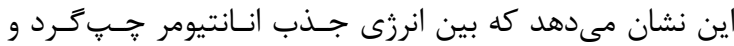

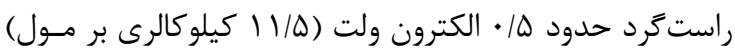
اختلاف انرزى وجود دارد و اين اختلاف انرزى، تا آخــرين كَام

زمانى ادامه داشته و به همين صورت حفظ مى شودود.

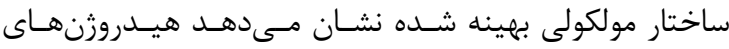

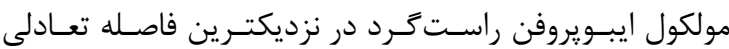

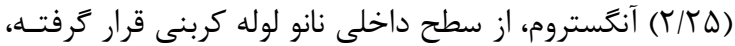

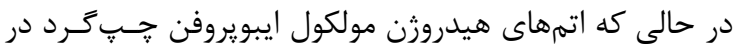

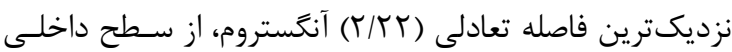

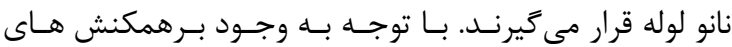

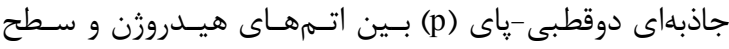

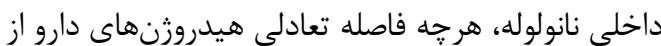

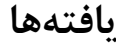

ابتدا خواص ساختارى انانتيومرهاى ايبويروفن و نانولوله كربنى

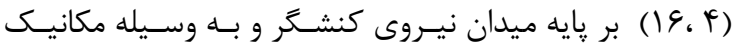

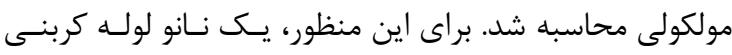

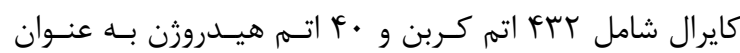

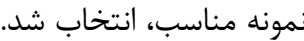

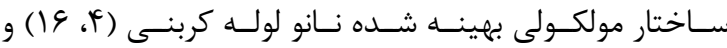

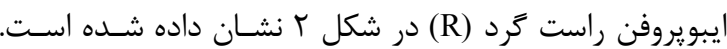

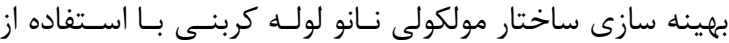

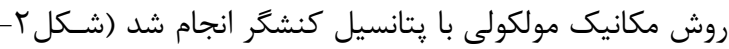

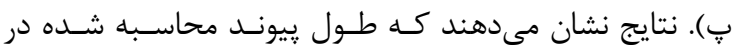
توافق بسيار خوبى با مقادير ززارش شده تجربى داشت و مقدار

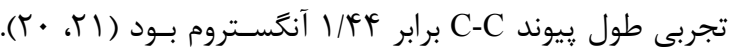

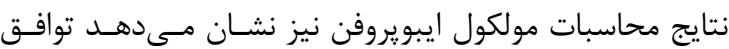

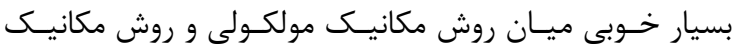
كوانتمى DFT وجود دارد (شكل r).

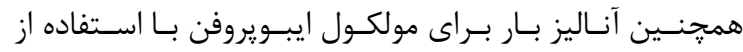

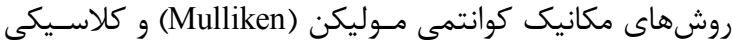
انجام شد. نتايج نشان مىدهند كه توافق خـوبى بــين دو روش مزبور در اندازه كيرى مقدار بار مستقر بر روى هر اتهم

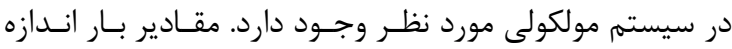

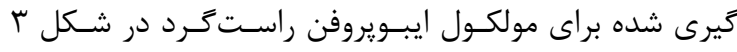

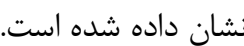
بعد از بهينه سازى ساختارهاى مولكـولى سيستمهـهـاى مـورد

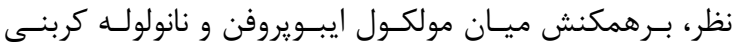

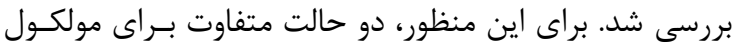

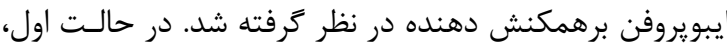

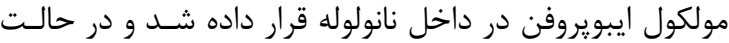
دوم به سطح خارجى نانولوله نزديك شد.

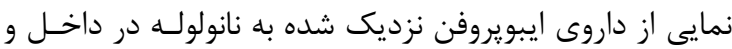
سطح خارجى نانولوله در شكل ^أ نشان داده شده است.

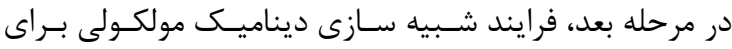

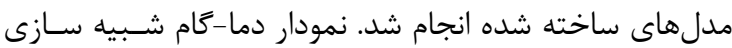
براى نمونه، براى يكى از سيستمهاى طراحى شــده، در نمـودار

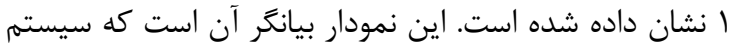

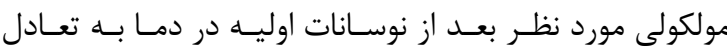
رسيده و با محيط هم دما مىشود. در واقع نمودار مزبور نشـان

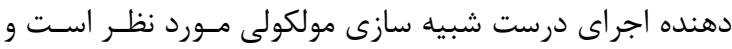

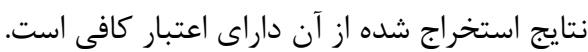




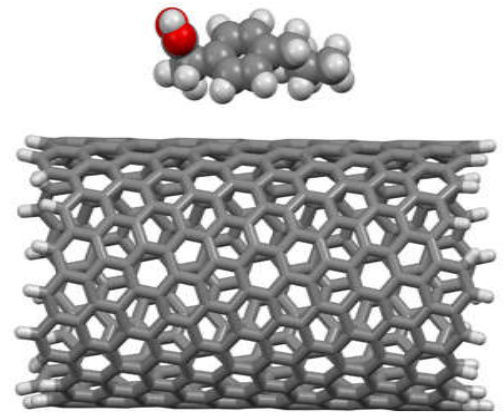

(ب)

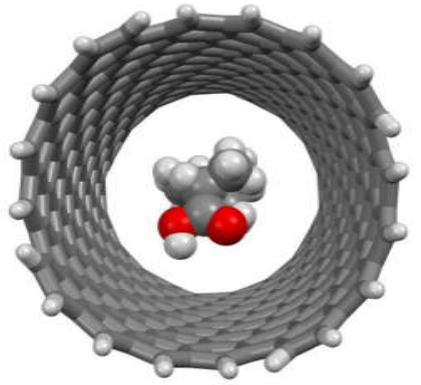

(I)

شكل F. نمايى از داروى ايبويروفن نزديك شده به نانولوله ، درسطح داخلى (آ) و خارجى (ب) نانولوله

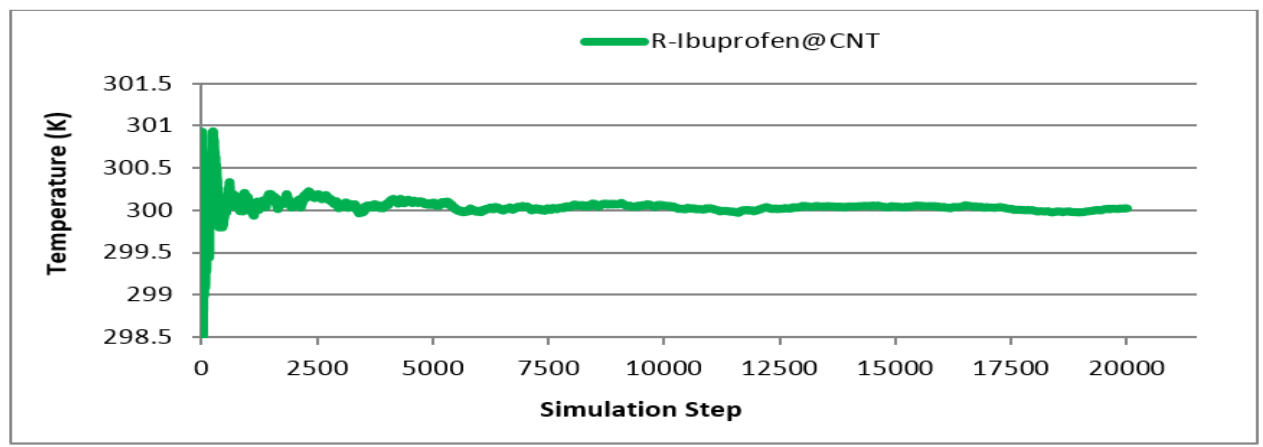

نمودار ا .دماى سيستم ايبويروفنونانو لوله كربنى (Y) (19)

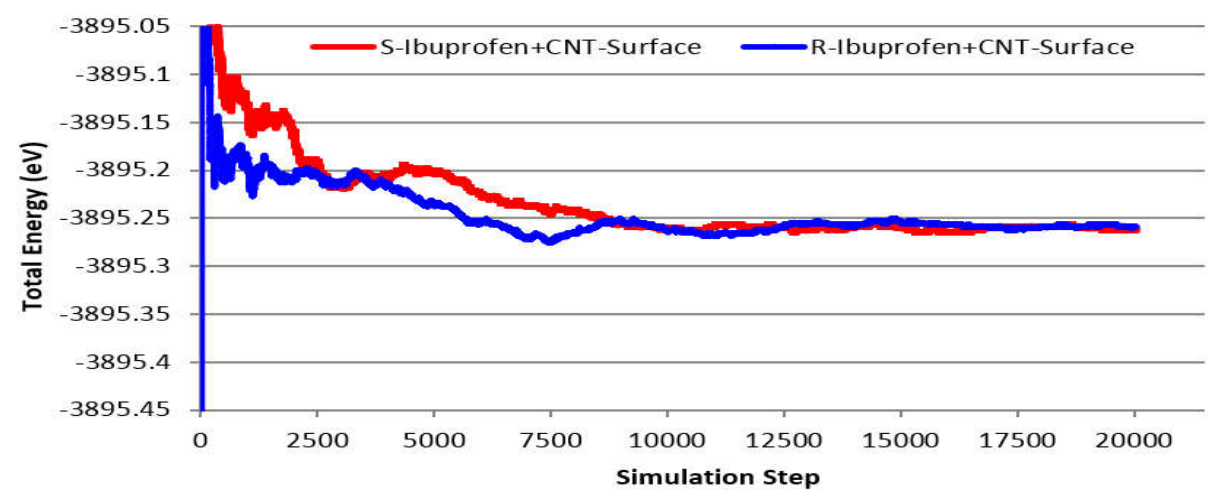

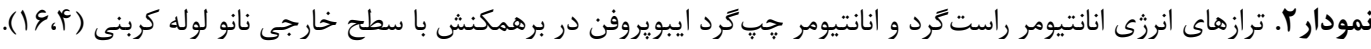

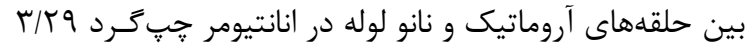
آنگستروم و در انانتيومر راستگرد اله/ آنگستروم اسـت. ايـن

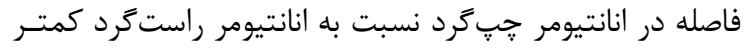

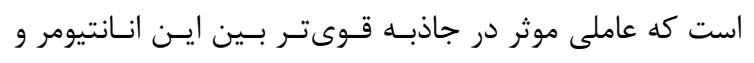
نانولوله و در نتيجه سطح انرزى پايينتر كميلكس است (شكل از طرف ديكر، اكسيرنهــاى مولكـول ايبـويروفن داراى جفـت الكترون ناييوندى و حلقه نانو لوله كربنى نيز داراى الكترونهاى مونى ياى است كه سبب ايجاد دافعه بين اكسيزنها و حلقه نانو لوله مىشود. در نتيجه، فاصله بيشتر اكسيزنها با سطح
سطح داخلـى نـانو لولـه كمتــر باشـد، جــذب بهتـرى صـورت مى گيرد. فواصل تعادلى مشاهده شده نشان مى نهد كه فاصـله

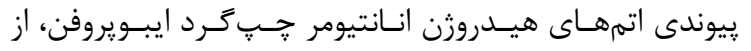

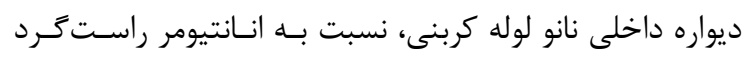

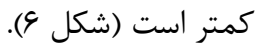
به علاوه ، با وجود برهمكنشهاى يـاى (p) بــين حلقـه فنيـل

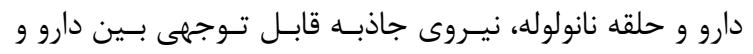
نانولوله بر قرار مىشود. در واقع فاصله كمتـر حلقـه فنيـل دارو

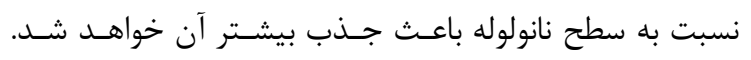

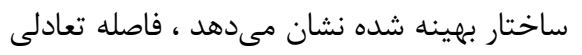



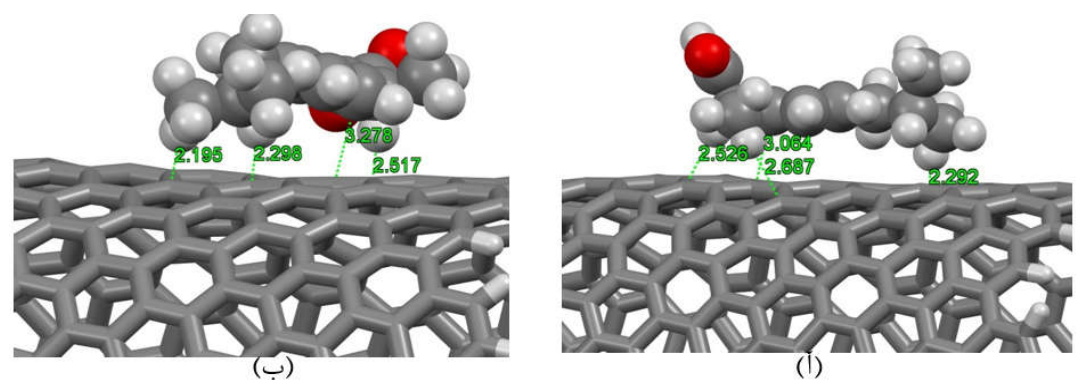

شكله. ساختار بهينه سازى شده براى انانتيومرهاى جֶٍ

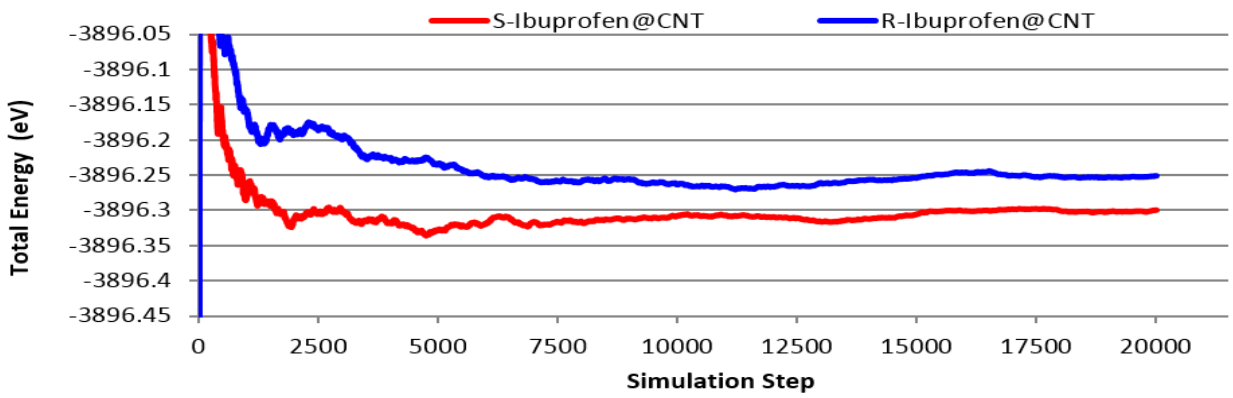

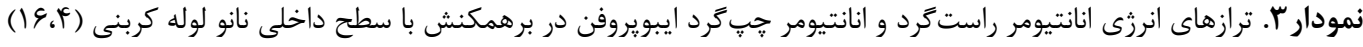

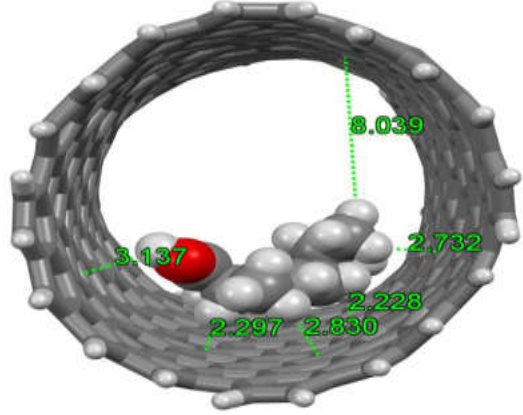

(ب)

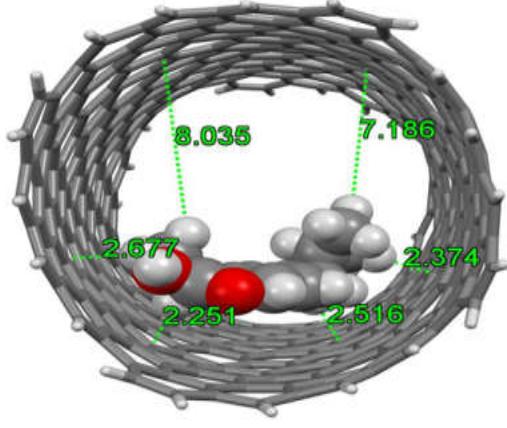

(I)

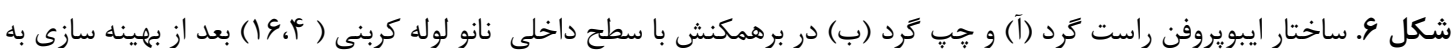
وسيله ميدان نيروى كنشخر

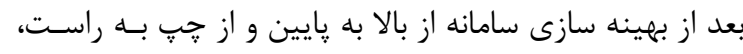

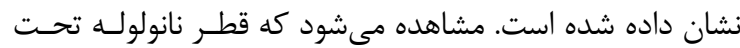
تاثير داروى كيسوله شده در داخل آن تغيير مى كند.

\section{بحث}

به طور كلى با توجه به اينكه، بين انـرزى جـذب انانتيومرهـاى

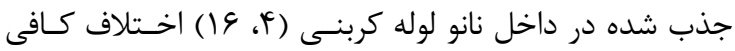
وجود دارد، مى توان انتظار داشت كــهـ ايـن نانولولـه در فرآينــد

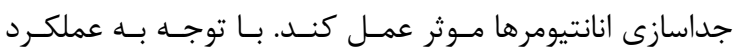
نانولوله كربنى در جداسازى ايزومرهاى دارويى، حداقل اختلاف
لوله، منجر به جذب بهتر دارو خواهد شد. فاصله اكسـيزنهـا و

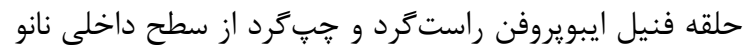
لوله، در شكل ^ نشان داده شـده اسـت. نزديـكتــرين فاصـله تعـادلى بـين اتـمهــاى اكسـيزن از سـطح داخلـى نانولولـهـ در

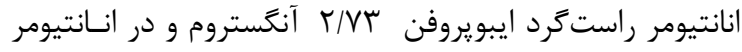

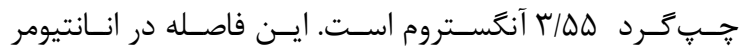
קֶֶ سطح انرزى اين سيستم پايينتر است. در ادامه، خواص ساختارى نانو لوله كربنـى و قطـر دهانـه نـانو لوله در برهمكنش با مولكول ايبـويروفن، بعـد از بهينـهـ سـازى

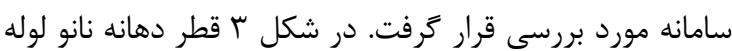




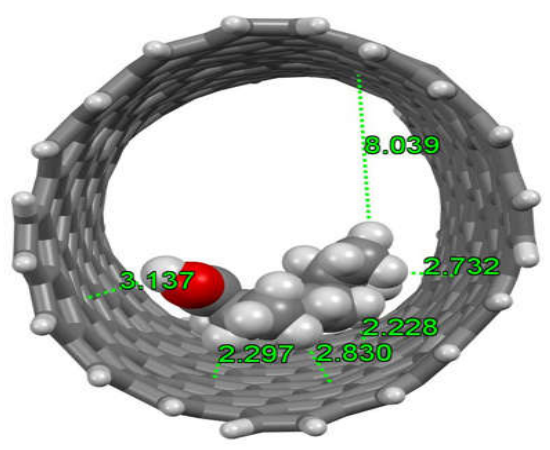

(ب)

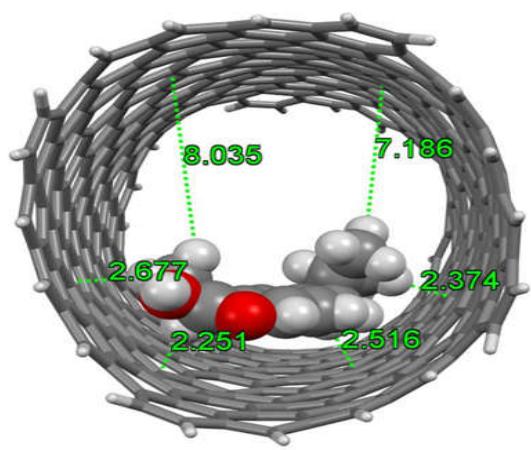

(I)

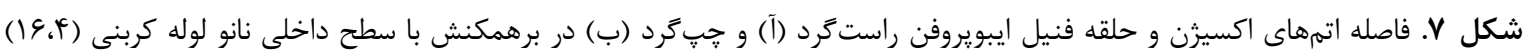

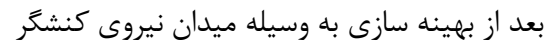

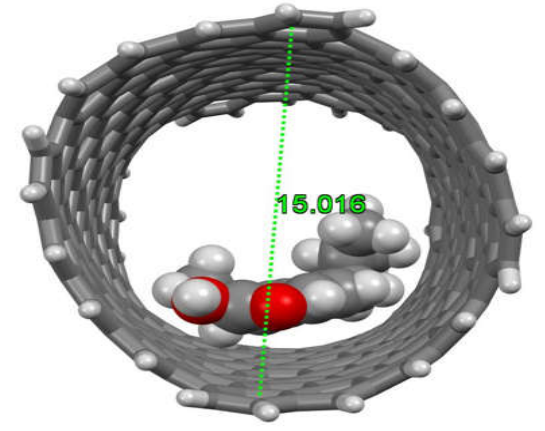

(ب)

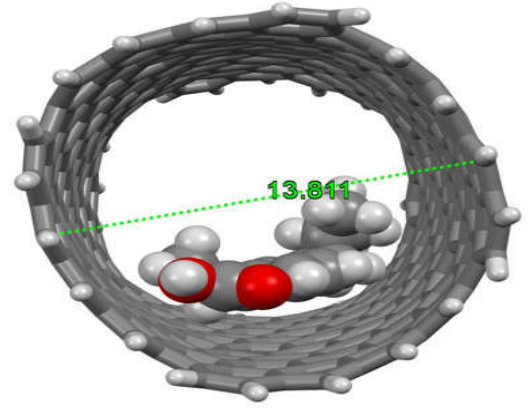

(I)

شكل ^. قطر دهانه نانولوله بعد از بهينه سازى سيستم (آ) از جٍٍ به راست و (ب) از بالا به پايين.

جدول ا. انرزى كل سيستم راست گرد، انرزى كل سيستم جِگرد واختلاف انرزى جذب انانتيومرها

\begin{tabular}{|c|c|c|c|}
\hline اختلاف انرزى انانتيومرها & انرزى كل سيستم جֶ & انرزى كل سيستم راست & \\
\hline.$/$ & $-\Lambda 9 \Lambda T F / 4 \&$ & $-\Lambda 9 \wedge r F / 4 G$ & سطح خارجى نانولوله \\
\hline $11 / \Delta r$ & $-\Lambda 9 \Lambda \uparrow \wedge / \varepsilon \Lambda$ & $-\Lambda 9 \Lambda F V / \Delta T$ & سطح داخلى نانولوله \\
\hline
\end{tabular}

حلقه نانو لوله، وجود دارد. همجنين بين اكسيزنهاى مولكـول

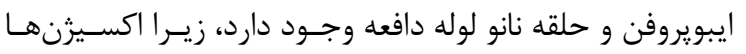
داراى جفت الكترون ناييوندى و حلقه نـانو لولـه كربنـى داراى الكترونهاى ياى است. در نتيجه فاصله بيشتر اكسيرنها منجر

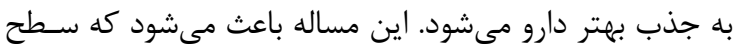

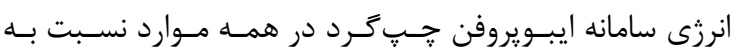
ايبويروفن راست گرد، يايينتــر باشـد و در نتيجــهـ ايسن سـامانه

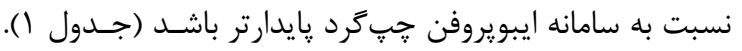

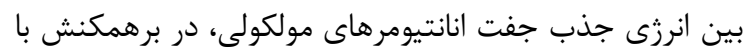

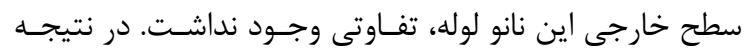

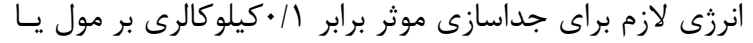

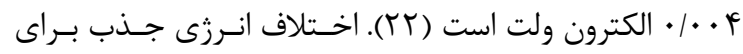
انانتيومرهاى جذب شده در داخـل نـانو لولـه كربنـى انتخــاب شده، برابر ه| • الكترون ولت است كه اين اختلاف انرزى بـراى جداسازى موثر، كافى است.

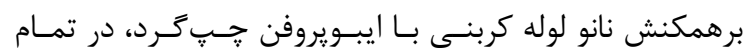
ساختارهاى بهينه شده به صورتى بود كه اتـمهـاى اكسـيرن از

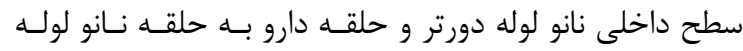

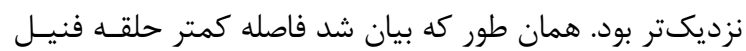

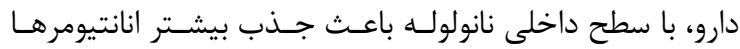
مىشود، زيرا برهمكنشهاى ياى (p) بـين حلقـه فنيـل دارو و 


\section{REFERENCES}

1. Von Heeren F, Thormann W. Capillary electrophoresis in clinical and forensic analysis. Electrophoresis 1997;18:2415-26.

2. Naylor S, Benson LM, Tomlinson AJ. Application of capillary electrophoresis and related techniques to drug metabolism studies. J Chromatogr A 1996;735:415-38.

3. Soleymani E, Alinezhad H, Ganji MD, Tajbakhsh M. Enantioseparation performance of CNTs as chiral selectors for the separation of ibuprofen isomers: A dispersion corrected DFT study. J Mater Chem B 2017;5:6920-9.

4. Hutt AJ, Valentová J. The chiral switch: The development of single enantiomer drugs from racemates. Acta Fac Pharm Univ Comenianae 2003;50:7-23.

5. Johannsen M. Separation of enantiomers of ibuprofen on chiral stationary phases by packed column supercritical fluid chromatography. J Chromatogr A 2001;937:135-8.

6. Schurig V. Separation of enantiomers by gas chromatography. J Chromatogr A 2001;906:275-99.

7. Scriba GKE. Review Pharmaceutical and biomedical applications of chiral capillary electrophoresis and capillary electrochromatography : an update. Electrophoresis 2003;2409-21.

8. Gallardo A, Roman JS, Barbas C, Cifuentes A, Simo C. Fast and sensitive capillary electrophoresis method to quantitatively monitor ibuprofen enantiomers released from polymeric drug. J Chromatogr B 2002;767:35-43.

9. Cizmáriková R, Valentová J, Hutta JA. Adrenergic beta-receptor blockers--a group of chiral drugs: enantioseparation in the group of beta-blockers. Ceska Slov Farm 2004; 53:9-17.

10. Bianco A, Kostarelos K, Prato M. Applications of carbon nanotubes in drug delivery. Curr Opin Chem Biol 2005;9:674-9.

11. Wright MR, Sattari S, Brocks DR, Jamali F. Improved high-performance liquid chromatographic assay method for the enantiomers of ibuprofen. J Chromatogr B Biomed Sci Appl 1992;583:259-65.

12. Shen TY. Perspectives in nonsteroidal anti-inflammatory agents. Angew Chem Int Ed Engl 1972;11: 460-472.

13. Esfandiarpoor S, Fazli M, Ganji MD. Reactive molecular dynamic simulations on the gas separation performance of porous graphene membrane. Sci Rep 2017;7:1-12.

14. Mueller JE, van Duin ACT, Goddard WA. Development and validation of ReaxFF reactive force field for hydrocarbon chemistry catalyzed by nickel. J Phys Chem C 2010;114:4939-49.

15. Gardam M, McGeer A, Mertz D. Portable ultraviolet light surface-disinfecting devices for prevention of hospitalacquired infections: a health technology assessment. Ont Health Technol Assess Ser 2018;18:1-73.

16. van Duin ACT, Dasgupta S, Lorant F, Goddard WA. ReaxFF: A reactive force field for hydrocarbons. J Phys Chem A. 2001;105:9396-409.

17. Cheung S, Deng W-Q, Duin ACT, Goddard WA. ReaxFF MgH Reactive Force Field for Hydride Systems. J Phys Chem A 2005;109:851-9.

18. Liu H, Chen Z, Dai S, Jiang DE. Selectivity trend of gas separation through nanoporous graphene. J Solid State Chem 2015;224:2-6.

19. Neese F. Software update: the ORCA program system, version 4.0. Wires Computational Molecular Science 2018;8:1327.

20. Saito R, Dresselhaus G, Dresselhaus MS. Trigonal warping effect of carbon nanotubes. Phys Rev B 2000;61:2981-90.

21. Jorio A, Saito R, Hafner JH, Lieber CM, Hunter M, McClure T, et al. Structural determination of isolated singlewall carbon nanotubes by resonant raman scattering. Phys Rev Lett 2001;86:1118-21.

22. Power TD, Skoulidas AI, Sholl DS. Can chiral single walled carbon nanotubes be used as enantiospecific adsorbents? J Am Chem Soc 2002;124:1858-9. 